\title{
Chemical Evaluation and Nutritive Value of Cultivated and Wild Gongronema latifolium Obtained in Etinan, Akwa Ibom State, Nigeria
}

\author{
E. I. Uwah, E. R. Mkpa \\ Department of Chemistry, University of Uyo, Nigeria
}

\begin{abstract}
The leaves of Gongronema latifolium (utasi) generally consumed as vegetables and spices for nutritional and medicinal purposes were analysed for chemical composition and nutritive value to ascertain the suitability of the plant for human consumption. The plant samples were collected from a cultivated farm and a wild forest in Etinan, Akwa Ibom State, Nigeria. The analyses were performed using standard analytical methods for food analysis. Qualitatively, phytochemical analysis revealed the presence of alkaloids, flavonoids, triterpenoids, glycosides, steroids and saponin in variable amounts in both the wild and the cultivated samples. Quantitatively, the results for phytochemical analysis ranged from $0.53 \pm 0.02 \%$ steroid in cultivated sample to $28.75 \pm 0.02 \%$ alkaloid in the wild sample. In the proximate analysis, the results ranged from $6.92 \pm 0.03 \%$ fibre in the cultivated sample to $65.06 \pm 0.09 \%$ moisture in the wild. The caloric value for the cultivated sample was $404.35 \pm 0.17 \mathrm{kcal}$ while that of the wild sample was $395.36 \pm 0.29 \mathrm{kcal}$. Results for the antinutrient analysis, ranged from $0.05 \pm 0.00 \mathrm{mg} / 100 \mathrm{~g} \mathrm{HCN}$ in the cultivated sample to $180.40 \pm 4.42 \mathrm{mg} / 100 \mathrm{~g}$ oxalate in the wild sample. The vitamin contents ranged from $0.01 \pm 0.00 \mathrm{mg} / 100 \mathrm{~g}$ vitamin $E$ in the wild sample to $42.14 \pm 0.03 \mathrm{mg} / 100 \mathrm{mg}$ vitamin $C$ in the cultivated sample. For the essential elements determination, the results ranged from $2.82 \pm 0.01 \mathrm{mg} / 100 \mathrm{~g} \mathrm{Fe}$ in the cultivated sample to $165.29 \pm 0.02 \mathrm{mg} / 100 \mathrm{~g} P$ in the cultivated sample, while the trace metals levels ranged from $0.01 \pm 0.00 \mathrm{mg} / 100 \mathrm{~g} \mathrm{Cd}$ and $\mathrm{Pb}$ in both the cultivated and wild samples to $3.44 \pm 0.03 \mathrm{mg} / 100 \mathrm{~g} \mathrm{Cu}$ in the wild sample. Arsenic (As) levels in the two samples were below the detection limit. Statistical test of significance using the student $t$-test showed significant difference $(p<0.05)$ between the cultivated and wild samples for most of the parameters analysed. There were high positive correlations at $p=$ 0.05 among the parameters analysed in the two samples. In general, the results revealed that the plant samples contain appreciable levels of phytochemicals, nutrients, essential elements and vitamins. The antinutrient or toxicant levels in the plant samples were however low. Similarly, the trace metals levels in the plant were below the levels that could cause phytotoxity in plants and toxicity in humans, hence, the suitability of the plant for human consumption both for nutritional and medicinal purposes.
\end{abstract}

Keywords: Chemical evaluation, consumption, cultivated, nutritive value, Gongronema latifolium, suitability, wild

\section{Introduction}

According to the United Nation Food and Agricultural Organization, about 805 million out of the 7.5 billion people in the world suffered from chronic undernourishment in 2012 - 2014. The organization maintained that almost all the hungry people (791million) lived in developing countries, representing 13.5 percent of the population of the developing countries [1]. Accordingly, there are about 11 million people undernourished in developed countries [1]. Much attention is centered on exploitation and utilisation of plant materials for food. The reliance on plants for food facilitates the supply of essential nutrients necessary for healthy growth and maintenance of life. According to [2 - 4], vegetables are edible portion (the leafy outgrowth) of plants usually used in soup or serving as an integral part of the main sources of our meals. Gongronema latifolium is a typical plant consumed as vegetables in Nigeria. The plant is commonly referred to as betel vine. It is a green leafy vegetable, a perennial herbaceous shrub with yellow flowers and stems with characteristics milky exudates when cut. Gongronema latifolium is generally called utasi by the Ibibios and the Efiks, utazi by the Igbos, arokeke by the Yorubas. It is found in the tropical rain forest and it is used as spice and vegetable in traditional medicine $[5,6]$. Research works from various authors revealed that G. latifolium contains essential oil and saponnins among others $[7,8]$. This plant has been identified to be nutritionally high in protein and amino acid [9]. According to [8], the leaf extract of Gongronema latifolium has anti-inflammatory among other properties. [10] noted that Gongronema latifolium and many other plants such as curry (Hyptis suaveolens), tea bush (Ocimum bassillicum) and climbing black pepper (Piper guineanse) are used as spices. Spices are plant chemicals which stimulate our taste buds. They are dried seed, fruit, root and bark or vegetable substances used primarily for flavouring, colouring or preserving of food. They are commonly used as chicken broth, oyster sauce, fish sauce, soup bases for instant noodles, many fast foods and restaurant dishes [11]. 
Gongronema latifolium is classified along with some other plants as being therapeutic to a lot of ailments as well as good sources of nutrients to the body. Most plants are useful for healing and curing of human diseases because of the presence of phytochemicals [12]. According to [10], phytochemicals are bioactive non nutritive plant chemicals that have protective or disease preventive properties. They are non essential nutrients and are not required by human body for sustaining life. These chemicals are produced naturally by plants to protect themselves. They are formed during plant's normal metabolic processes [13]. Phytochemicals are classified into primary and secondary components or metabolites. Chlorophyll, protein and common sugars fall under primary component where as secondary components include terpeniods, alkaloid, flavanoids, coumarins, glycosides, gums tannins, steroid, polysaccharides and phenols [14, 15]. Terpeniods exhibit various important pharmacological activities such as anti inflammatory, anti cancer, anti-malaria, inhibition of cholesterols synthesis, anti-viral and anti-bacterial activities. Alkaloids are used as aesthetic agents and are found in medicinal plants [16]. Phytochemicals such as $\beta$ - sistosterol. lupeoyl ester, glycosides, saponins are known to be associated with Gongronema latifolium $[17,7]$. G. latifolium is used for treatment of malaria, diabetes and hypertension due to its antioxidant, anti- inflammatory and anti microbial among other properties [6, 18]. Diets that are rich in fresh fruits and vegetables are known to be protective against chronic degenerative disease [19].

Vegetables supply the body with the needed nutrients. Fruits and vegetables such as carrots, mango, papaya and melon contain large amounts of nutritionally active metabolites [20, 21]. Green leafy vegetables such as ivy gourd have been successfully used in Thailand as a source of vitamin A. The biological activity of vitamin A varies among different plant sources. The function of vitamin A is at two levels in the body. The first is in the visual cycle in the retina of eye; the second is in all body tissues systemically to maintain growth and soundness of the cells [22]. Vitamin A deficiency leads to night blindness mostly prevalent in children under 3 years of age [23]. Women of reproductive age are thought to be vulnerable to vitamin A deficiency during pregnancy and lactation because they are often reported of having night blindness [24]. Vitamin $\mathrm{C}$ (Ascorbic acid or ascorbate) is a water soluble vitamin, a six-carbon compound $\left(\mathrm{C}_{6} \mathrm{H}_{8} \mathrm{O}_{6}\right)$ structurally related to glucose, consisting of two inter-convertible compounds: L-ascorbic acid, which is a strong reducing agent and its oxidized derivative, L-dehydroascorbic acid [25, 26]. It is found in many fruits and vegetables. As an antioxidant, vitamin $\mathrm{C}$ is a free radical scavenger or neutralizer and protects the body against cancers, heart diseases, stress and helps in maintaining a healthy immune system [26 - 28]. Lack or insufficiency of vitamin C in the diet of humans will lead to the potentially lethal deficiency disease called scurvy [29, 26]. Scurvy is characterized by weakness, small hemorrhages throughout the body that cause gums and skin to bleed and loosening of the teeth [26]. Other antioxidants include vitamin E, the carotenoids and several minerals. Antioxidants protect large molecule from being damaged. It is an established fact that free radicals, especially super oxide, nitric oxide and other reactive species such as $\mathrm{H}_{2} \mathrm{O}_{2}$ are continuously produced in vivo. Vitamin $\mathrm{E}$ is an example of phenolic or aromatic amines antioxidants, such molecules readily donate hydrogen from the hydroxyl $(-\mathrm{OH})$ group on the ring structure to free radicals which then become unreactive. On donating the hydrogen, the phenolic compound itself becomes a relatively unreactive free radical because of unpaired election on the oxygen atom which is usually delocalized into aromatic ring structure thereby increasing its stability [30]. Should our exposure to free radicals exceed the protective capacity of the antioxidants defense system, a phenomenon often referred to as oxidative stress may occur which could lead to damage of the biological molecule [31]. Vitamin $\mathrm{E}$ is the major lipid-soluble antioxidant in the cell antioxidant defense system. Muscle and neurological problems are consequences of human vitamin E deficiency [32].

Leafy vegetables contribute immensely in the provision of mineral elements in the body system. Calcium is essentially a nutrient that plays a vital role in neuromuscular functions, many enzyme-mediated processes, blood clothing and providing rigidity to the skeleton by virtue of its phosphate salts. In population with long-standing iron deficiency, a reduction of physical working capacity has been demonstrated by several groups with improvement in working capacity after iron administration [33]. Soft tissue magnesium functions as a co-factor of many enzymes involved in energy metabolism, protein synthesis, RNA and DNA synthesis, and maintenance of electrical potential of nervous tissues and cell membrane [34]. Zinc plays central role in the immune system, affecting a number of aspect of cellular and Humoral immunity [35].

Globally, there is high demand for evaluation of chemical composition and nutritive value of tropical plants, many of which are medicinal. This necessitates more work on Gongronema latifolium as regarding the nutritional and medicinal values as well as food processing and preservation. These would reduce the current use of synthetic chemicals in drug manufacturing, food processing and other processes. In Etinan, Akwa Ibom State, Gongronema latifolium are generally found growing in natural conditions in the wild forest and equally cultivated in farms and consumed as vegetables and spices. The leaves extracts of the plant are known by the local populace to have curative properties and hence the plant is used locally for curing most abdominal pains. This study goes a long way to establish the chemical, nutritional, curative and or toxicological properties in the wild and cultivated plant samples, thereby ascertaining the suitability of the plant for human consumption, both nutritional and medicinal purposes or otherwise. This study will be useful for the nutritional and medicinal 
education of the public with a view to improving the nutritional and medicinal status of the population.

\section{II.1. Sample Collection}

\section{Materials And Methods}

Freshly harvested samples of Gongronema latifolium (utasi) were collected from Etinan, Akwa Ibom State. The plant samples were randomly collected from a cultivated farm and a wild forest. Samples from each area were pooled together to obtain two composite samples. The plant was authenticated by a Taxonomist in the Department of Botany and Ecological studies, University of Uyo. The leaves of the plant were used for the various aspects of analyses.

\section{II.2. Phytochemical Analysis (Qualitative)}

Qualitative tests were carried out on the extracts of air dried powdered samples of the plant (cultivated and wild) using standard procedures as described by [36 - 38].

\section{II.2.1.Test for Alkaloid}

Extracts (2.0) $\mathrm{g}$ were dissolved individually in $2 \mathrm{~cm}^{3}$ of $10 \%$ hydrochloric acid and filtered. Filtrates were (a) treated with $1 \mathrm{~cm}^{3}$ mayers reagent (potassium mercuric iodine) or $1 \mathrm{~cm}^{3}$ Hager's reagent (saturated picric acid solution). Formation of a yellow coloured precipitate indicates the presence of alkaloids and (b) treated with Dragendrof's reagent (solution of potassium, bismuth, iodine). Formation of red precipitate indicates the presence of alkaloid.

\section{II.2.2. Test for Flavonoids}

A portion $(0.2 \mathrm{~g})$ of each of the extract was heated with $10 \mathrm{~cm}^{3}$ of ethyl acetate over a steam bath for three minutes, the mixture was filtered and $4 \mathrm{~cm}^{3}$ of the filtrate were shaken with $1 \mathrm{~cm}^{3}$ of dilute ammonia. A yellow colouration indicates the presence of flavonoids.

\section{II.2.3. Test for Saponins}

A portion $(0.5 \mathrm{~g})$ of each of the extract was added to $5 \mathrm{~cm}^{3}$ of distilled water in a test tube and the resulting solution shaken vigorously and observed for a stable persistent froth. The frothing was mixed with 3 drops of olive oil and shaken vigorously. Formation of an emulsion indicates the presence of saponins.

\section{II.2.4. Test for Tannins}

Ten $(10) \mathrm{cm}^{3}$ of freshly prepared $10 \%$ potassium hydroxide was added to $0.5 \mathrm{~g}$ of each of the extracts in a beaker and shaken to dissolve. A dirty precipitate indicates the presence of tannins

\section{II.2.5. Test for Steroids}

A portion $(0.5 \mathrm{~g})$ of each of the extracts was dissolved in $10 \mathrm{~cm}^{3}$ of chloroform and equal volume of concentrated sulphuric acid added along sides of the test tubes. Reddish upper layer and yellowish sulphuric acid layer with green fluorescence indicate the presence of steroids.

\section{II.2.6. Test for Glycosides}

Exactly $2 \mathrm{~cm}^{3}$ of acetic acid were added to $2 \mathrm{~cm}^{3}$ of each extracts. The mixture was cooled in a cold water bath and $2 \mathrm{~cm}^{3}$ of concentrated $\mathrm{H}_{2} \mathrm{SO}_{4}$ was added. Colour development from blue to bluish green indicates the presence of glycosides.

\section{II.2.7 Test for Triterpenoids}

Accurate amount of $0.5 \mathrm{~g}$ of each of the extract was dissolved in $1 \mathrm{~cm}^{3}$ of chloroform. About $\mathrm{cm}^{3}$ of acetic anhydride was added, followed by the addition of $2 \mathrm{~cm}^{3}$ of concentrated $\mathrm{H}_{2} \mathrm{SO}_{4}$. Formation of reddish violet colour indicates the presence of triterpenoids.

\section{II.3. Quantitative Phytochemical Analysis \\ II.3.1. Determination of Saponins}

The process of extraction of saponin in the samples was done from the method described by [39]. The extraction process was carried out in two different solvents, acetone and methanol. Acetone was first used for the removal of crude lipid and methanol was used for the extraction of saponin from the sample. Accurate amounts of $2.0 \mathrm{~g}$ of each sample were folded into a thimble and placed in a Soxhlet extractor and a reflux condenser fitted on top and extraction performed with acetone in a round bottomed flask for 3 hours. The apparatus was dismantled and another flask containing $100 \mathrm{~cm}^{3}$ of methanol (whose weight was taken when empty) was fitted to the extractor and the extraction performed for another 3 hours. At the end of the second 
extraction, the methanol was recovered by distillation and the flask properly oven-dried, allowed to cool and the weight taken. The saponin content $(\mathrm{mg} / 100 \mathrm{~g})$ was then calculated from:

Saponin content $(\mathrm{mg} / 100 \mathrm{~g})=\underline{\mathrm{W}}_{2} \underline{\mathrm{x}} \mathrm{W}_{\mathrm{S}} \times 100$

Where: $\mathrm{W}_{2}=$ weight of flask and extract; $\mathrm{W}_{1}=$ weight of empty flask; $\mathrm{W}_{\mathrm{S}}=$ weight of sample.

\section{II.3.2. Determination of Glycosides}

Glycosides in general, are substances derived from plants which upon hydrolysis, yield sugar and one or more additional product. The method of analysis was as described by [39].

One (1)g of air-dried and milled of each sample was weighed into separate $250 \mathrm{~cm}^{3}$ round-bottom flask. A total of $200 \mathrm{~cm}^{3}$ of distilled water was added into the flask and allowed to stand for two hours (for autolysis to occur). Full distillation was carried out and $150-170 \mathrm{~cm}^{3}$ of distillate were collected in $250 \mathrm{~cm}^{3}$ conical flask containing $20 \mathrm{~cm}^{3}$ of $2.5 \% \mathrm{NaOH}$. Silicon oil or tannic acid (anti-foaming agent) was added before distillation. An accurate volume of $8 \mathrm{~cm}^{3}$ of $6 \mathrm{M} \mathrm{NH} \mathrm{NH}_{4} \mathrm{OH}$ and $2 \mathrm{~cm}^{3}$ of $5 \% \mathrm{KI}$, were added to $100 \mathrm{~cm}^{3}$ of the distillate containing glycoside. This was mixed and titrated with $0.02 \mathrm{M}$ silver nitrate $\left(\mathrm{AgNO}_{3}\right)$, using a micro burette against a black background. The end point was indicated with permanent turbidity. The amount of glycoside $(\%)$ was obtained from the following calculation:

Glycoside $(\%)=\left[\right.$ Titre $\left(\mathrm{cm}^{3}\right) \times 1.08 \times$ extract $\left.\left(\mathrm{cm}^{3}\right) \times 100\right] \div\left[\right.$ Aliquot $\left(\mathrm{cm}^{3}\right) \times$ sample weight $\left.(\mathrm{g})\right]$

\section{II.3.3. Determination of Alkaloid}

Alkaloid determination in the samples was done according to the methods described by [40, 41]. Five (5) $\mathrm{g}$ of each sample were taken in a $250 \mathrm{~cm}^{3}$ beaker and $100 \mathrm{~cm}^{3}$ of $100 \%$ acetic acid in ethanol were added into each sample, covered and allowed to stand for four (4) hours. These were then filtered and the filtrates concentrated on a water bath to a quarter (1/4) of the original volume. Concentrated ammonium hydroxide was added drop-wise to the concentrated filtrates until the precipitate was complete. The whole solution was allowed to settle and the precipitate was collected and washed with dilute ammonium hydroxide and then filtered. The filter paper was dried with the residue and re-weighed. The amount (\%) alkaloid in each sample was obtained from:

$\%$ Alkaloid $=\left[\left(\mathrm{W}_{2}-\mathrm{W}_{1}\right) \quad \mathrm{x} \quad 100\right] \div[$ weight of sample $]$

Where: $\mathrm{W}_{1}=$ weight of empty filter paper; $\mathrm{W}_{2}$ = weight of filter paper + alkaloid precipitate.

\section{II.3.4. Determination of Flavonoid}

Accurate amount of $2.5 \mathrm{~g}$ of the plant samples were extracted repeatedly with $100 \mathrm{~cm}^{3}$ of $80 \%$ aqueous methanol at room temperature and allowed to stand for 45 minutes. The extracts were filtered through Whatman filter paper No. 42. The filtrate was later transferred into a beaker/crucible and evaporated to dryness over a water bath and weighed. The formula below was used to establish the amount of flavonoid (\%) present. $\%$ Flavonoid $=\left[\left(\mathrm{W}_{2}-\mathrm{W}_{1}\right) \times 100\right] \div[$ weight of sample $] ..$

Where: $\mathrm{W}_{1}$ = weight of the empty beaker; $\mathrm{W}_{2}$ = weight of empty beaker + sample after drying.

\section{II.3.5. Determination of Steroids}

Steroid content of plant sample was determined using the method described by [37]. Two (2) $\mathrm{cm}^{3}$ was taken from a solution of $2.5 \mathrm{~g}$ of powdered material prepared in $50 \mathrm{~cm}^{3}$ of distilled water after vigorously shaking for one hour. The extract solution was washed with $3 \mathrm{ml}$ of $0.1 \mathrm{M} \mathrm{NaOH}(\mathrm{pH}=9)$ and later mixed with $2 \mathrm{~cm}^{3}$ of chloroform and $3 \mathrm{~cm}^{3}$ of ice cold acetic anhydride followed by adding two drops of concentrated $\mathrm{H}_{2} \mathrm{SO}_{4}$ cautiously. The absorbance of both sample and blank were measured spectrophotometrically at 420nm.

\section{II.4. Antinutrient Analysis}

\section{II.4.1. Determination of Tannins}

Tannins in the samples were determined by the methods of [42, 43] and the Follin-Dennis Spectrophotometric method as described by [44]. Accurate amount of $0.5 \mathrm{~g}$ of the powdered sample was taken in a conical flask and $100 \mathrm{~cm}^{3}$ of distilled water added. This was gently boiled for one hour and then filtered into a $100 \mathrm{~cm}^{3}$ capacity volumetric flask. The filtrate was diluted to the $100 \mathrm{~cm}^{3}$ mark and then cooled. For the greenish-blue colour development, $50 \mathrm{~cm}^{3}$ aliquot were put into the flask. This was followed by the additions of $5 \mathrm{~cm}^{3}$ Folin - Dennis reagent and $10 \mathrm{~cm}^{3}$ of saturated sodium carbonate solution and then diluted to the $100 \mathrm{~cm}^{3}$ mark with distilled water. After thorough mixing, the flask was allowed to stand in a water bath at $25^{\circ} \mathrm{C}$ for 20 minutes and the optical density measured at $700 \mathrm{~nm}$. Distilled water was used as blank regarding the calibration curve. Standard tannic acid solutions were prepared from which a standard curve was made (absorbance versus 
concentration in $\mathrm{mg} / \mathrm{cm}^{3}$ ). From this curve, the concentration of each sample was obtained and used for the tannin content calculation as shown below:

Tannin content $(\mathrm{mg} / 100 \mathrm{~g})=\frac{\mathrm{C} \times \mathrm{V}_{\mathrm{ex}}}{\mathrm{W}_{\mathrm{S}} \times \mathrm{A}}$

Where: $\mathrm{C}=$ concentration $(\mathrm{mg})$ from standard curve; $\mathrm{V}_{\mathrm{ex}}=$ volume of the extract $\left(\mathrm{cm}^{3}\right)$;

$\mathrm{A}=$ aliquot $\left(\mathrm{cm}^{3}\right)$ and $\mathrm{W}_{\mathrm{S}}=$ weight of sample $(\mathrm{mg})$

\section{II.4.2. Determination of Oxalates}

Determination of oxalates in the samples was performed by the method described by [45]. In this method, $1.0 \mathrm{~g}$ of the dried powdered sample was extracted thrice by warming at $40-50^{\circ} \mathrm{C}$ and stirring with a magnetic stirrer for 1 hour with $20 \mathrm{~cm}^{3}$ of $0.3 \mathrm{~N} \mathrm{HCl}$. The extract was diluted to $100 \mathrm{~cm}^{3}$ with distilled water and used for the total oxalate determination in which $5.0 \mathrm{~cm}^{3}$ of the extract was made alkaline with $1.0 \mathrm{~cm}^{3}$ of $5.0 \mathrm{~N}$ $\mathrm{NH}_{4} \mathrm{O} \mathrm{H}$. This was followed by the additions of 2 to 3 drops phenolphthalein indicator and $1.0 \mathrm{~cm}^{3}$ of $5 \%$ calcium chloride. The mixture was allowed to stand for 3 hours after which it was centrifuged at 3000 revolutions per minute (rpm) for 15 minutes. The supernatant was discarded and the precipitate washed thrice with hot water with mixing and centrifuging each time. About $2.0 \mathrm{~cm}^{3}$ of $3 \mathrm{~N} \mathrm{H}_{2} \mathrm{SO}_{4}$ was added and the precipitate dissolved by warming in a water bath at about $70-80^{\circ} \mathrm{C}$. The resulting solution was then titrated at room temperature with freshly prepared $0.01 \mathrm{~N}$ potassium permanganate solution until the first pink colour appeared throughout the solution which on standing, the pink colour disappeared. The solution was then warmed at $70-80^{\circ} \mathrm{C}$ and titration continued until a second prink colour which persisted for at least 30 seconds appeared. The total oxalate content $(\%)$ in the sample was then obtained from the following equation:

$\%$ Total oxalate $=\underline{\text { Weight } \text { of extract }} \times 100$

$$
\text { Weight of sample }
$$

\section{II.4.3. Determination of Phytates}

This was done using the method of [46]. A total of $100 \mathrm{~cm}^{3}$ of each sample were extracted with $3 \%$ trichloroacetic acid (TCA). The extracts were treated with $\mathrm{FeCl}_{3}$ solution and the iron contents of the precipitates formed were determined using AAS. The phytic acid contents were then calculated using a 4:6 Fe/P atomic ratio [47].

\section{II.4.4. Determination of Hydrocyanic Acid}

This was done using the alkaline titration method as described by [39]. A total of $100 \mathrm{~cm}^{3}$ of each sample extract was steam-distilled into a solution of $\mathrm{NaOH}$. The distillate was treated with dilute KI solution. This was then titrated against $0.02 \mathrm{M} \mathrm{AgNO}_{3}$ solution until it changes from clear to a faint but permanent turbid solution, indicating the endpoint. The hydrogen cyanide content in the samples was determined by taking $1 \mathrm{~cm}^{3}$ of $0.02 \mathrm{M} \mathrm{AgNO}_{3}$ as equivalent to $1.08 \mathrm{mg}$ hydrogen cyanide $(\mathrm{HCN})$.

\section{II.5. Proximate Analysis}

The methods of [39] were used for the determination of moisture, ash, crude protein, fibre, carbohydrate, crude lipids, nitrogen and dry matter contents of the plant samples.

\section{II.5.1. Determination of Moisture Content}

Thermal drying method was used in the determination of moisture content of the samples. Dried weights $(2.0 \mathrm{~g})$ of each sample were taken in washed, dried and weighed crucible. Each sample was placed in an oven and dried at $105^{\circ} \mathrm{C}$ for three hours. The sample was allowed to cool in a desiccator and then reweighed. The percentage moisture content was calculated by computing or expressing the loss in weight on drying as a fraction of the initial weight of sample used and multiplied by 100 as indicated below:

Moisture (\% wet weight) $=\frac{b-c}{b-a} \times 100$

Where: $\mathrm{a}=$ weight of crucible

$\mathrm{b}=$ weight of crucible + sample before oven drying

$\mathrm{c}=$ weight of crucible + sample after oven drying

\section{II.5.2. Determination of Crude Protein}

Determination of crude protein in the samples was done by first of all determining the total organic nitrogen (TON) using the macro-Kjeldhal method. This involved digestion, distillation and titration. Exactly $1.0 \mathrm{~g}$ of each sample was taken in digestion flasks. Few granules of anti-bumps and about $3.0 \mathrm{~g}$ of copper catalyst mixture (96\% anhydrous sodium sulphate, $3.5 \%$ copper sulphate and $0.5 \%$ selenium dioxide) were added. The samples were then digested by adding $20 \mathrm{~cm}^{3}$ concentrated sulphuric acid and heating on a heating 
mantle. Digestion was made to continue until a clear solution was obtained and the flasks were allowed to cool. The digests were then filtered and made up to $100 \mathrm{~cm}^{3}$ with distilled water. About $20 \mathrm{~cm}^{3}$ of the diluted digests were taken in a round-bottomed flask for distillation. The distillation was done by setting the round-bottomed flask connected to a receiving flask containing $20 \mathrm{~cm}^{3}$ of $2 \%$ boric acid with methyl red indicator on a heating mantle. About $30 \mathrm{~cm}^{3}$ of $40 \%$ sodium hydroxide was then injected into the flask and the ammonia formed was distilled by heating the flask. The distillation process was made to continue until the boric acid solution completely changed from purple to greenish - yellow. The boric acid mixture (containing the ammonium borate complex formed) was then titrated with $0.1 \mathrm{~N} \mathrm{HCl}$ to colourless end point and the sample titre noted. The blank determination was also carried out in a similar manner accept for the omission of the sample and the blank titre noted. The $\%$ TON was then calculated using the formula:

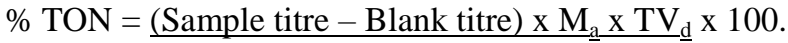

\section{Weight of sample $\mathrm{x} \mathrm{V}_{\mathrm{d}}$}

Where: $\mathrm{M}_{\mathrm{a}}=$ molarity of the acid; $\mathrm{TV}_{\mathrm{d}}=$ total volume to which digest was diluted

$\mathrm{V}_{\mathrm{d}}=$ volume of digest distilled

The $\%$ crude protein was obtained by multiplying the $\%$ TON content by a factor, 6.25 .

Hence, $\%$ Crude protein $=\%$ TON $x$ factor $(6.25)$. not well defined.

The value, 6.25 is a general factor suitable for products in which the proportions of specific proteins are

\section{II.5.3. Determination of Crude Lipid}

Determination of crude lipid contents of the samples was done using Soxhlet type of the direct solvent extraction method. The solvent used was petroleum ether (boiling range $40-60^{\circ} \mathrm{C}$ ). Exactly $2.0 \mathrm{~g}$ of the dried samples were taken in a soxhlet extraction thimble. The thimble was then put into $20 \mathrm{~cm}^{3}$ capacity soxhlet extractor. A washed, oven-dried $100 \mathrm{~cm}^{3}$ capacity round-bottomed flask was weighed and approximately $60 \mathrm{~cm}^{3}$ of the $40-60^{\circ} \mathrm{C}$ boiling range petroleum ether added. The flask was then mounted on the heating mantle and connected to the extractor with a condenser. The condenser and heating mantle were then activated and extraction carried out for four hours. At the end of extraction, the solvent was evaporated and the flask dried in the oven at $60^{\circ} \mathrm{C}$. The flask was then cooled and reweighed. The amount of crude lipid (\%) was calculated using the formula:

$$
\% \text { crude lipid }=\frac{\text { weight gain in flask }}{\text { weight of sample }}
$$

OR

$$
\% \text { crude lipid } \quad=\frac{\mathrm{W}_{2}}{\mathrm{~W}_{\mathrm{S}}} \frac{-\mathrm{W}_{1}}{1} \times 100
$$

Where: $\mathrm{W}_{2}=$ weight of beaker + sample

$\mathrm{W}_{1}=$ weight of empty beaker only; $\mathrm{W}_{\mathrm{S}}=$ weight of sample

\section{II.5.4. Determination of Ash Content}

The ash contents of each sample were determined using the ignition method. The crucibles used were thoroughly washed and pre-heated in a muffle furnace to about $600^{\circ} \mathrm{C}$. Exactly $2.0 \mathrm{~g}$ of each of the oven-dried sample used in moisture determination were taken in pre-heated, cooled and weighed crucibles and then reweighed. The crucibles were covered with lids and placed in a cold muffle furnace and heated at $600^{\circ} \mathrm{C}$ for two hours to burn off all the organic matters. The crucibles were removed from the furnace, allowed to cool in a desiccator and reweighed. The ash contents (\%) were calculated using the formula:

$$
\text { Ash } \%=\frac{\text { weight of ash }}{\text { weight of sample }} \times 100
$$

OR

$$
\mathrm{Ash} \%=\frac{\mathrm{c}-\mathrm{a}}{\mathrm{b}-\mathrm{a}} \times 100 .
$$

Where: $\mathrm{a}=$ weight of empty crucible

$\mathrm{b}=$ weigh of crucible + sample before ashing

$\mathrm{c}=$ weight of crucible + ash

\section{II.5.5. Crude Fibre Determination}

Two (2.0)g of each sample were taken in petroleum ether for two hours and then boiled under reflux apparatus for 30 minutes with $200 \mathrm{~cm}^{3}$ of a solution containing $1.25 \%$ of $\mathrm{H}_{2} \mathrm{SO}_{4}$ per $100 \mathrm{~cm}^{3}$ solution. After series of filtering and washing with boiling water to remove the acid, the residues were transferred into beakers 
and boiled for another 30 minutes with $200 \mathrm{~cm}^{3}$ of solution containing $1.25 \mathrm{~g}$ of NaOH per $100 \mathrm{~cm}^{3}$. The final residues were filtered and washed with boiling water until they were neutral to litmus and finally washed twice with ethanol and quantitatively transferred into pre-weighed crucibles and oven dried at $105^{\circ} \mathrm{C}$. The sample residues were then incinerated in a furnace at $550^{\circ} \mathrm{C}$ and allowed to stand at this temperature for 2 hours. The crucibles were later removed and allowed to cool in a desiccator and then reweighed. The crude fibre content of each sample was estimated according to the expression below:

$\%$ Crude fibre $=$ weight loss on ignition $(\mathrm{g}) \times 100$.

OR $\%$ Crude fibre $=\frac{1_{a}-1_{0}}{\text { original weight of sample taken }} \times 100$

Where: $1_{\mathrm{o}}=$ weight of empty crucible

$1_{\mathrm{a}}=$ weight of crucible and its contents after incineration

\section{II.5.6. Determination of total Carbohydrates}

Total carbohydrates in each sample were estimated by the differences obtained after subtracting the sum of the percentages of all the other proximate components from 100. That is, Total carbohydrates $(\%)=100$ $-(\%$ moisture $+\%$ crude protein + fibre $+\%$ crude lipid $+\%$ ash $)$.

Accordingly, the calorific value $(\mathrm{Kcal} / 100 \mathrm{~g})$ of each sample was calculated using the Atwater factors of 4, 9 and 4 for protein, fat and carbohydrate, respectively, as reported by [12].

\section{II.6. Determination of Mineral Elements Composition}

The method adopted for the determination of mineral elements composition of the samples was as described by [39]. The procedures included digestion of ashed samples, preparation of stock solution of each element and the determination of the concentration of the element using their absorbance read from atomic absorption spectrophotometer (AAS). The samples were dried in an oven set at $60^{\circ} \mathrm{C}$. One (1)g of each dried sample was ground into powdered form with a manual blender. The ground sample was taken in a crucible and ashed in a furnace at $500^{\circ} \mathrm{C}$ for four hours. The resulting ash was leached with $5 \mathrm{ml}$ of $6 \mathrm{M} \mathrm{HCl}$ and filtered. The filtrate was made up to $30 \mathrm{~cm}^{3}$ with deionised water. This served as the digestion solution for the detection of metals present in the samples using the AAS. The absorbance reading for the elements were recorded at appropriate wave lengths and the concentration of each element determined by extrapolation from the calibration curves earlier prepared from the standard solutions of the respective metals.

The levels of phosphorus in the samples were determined by colorimetric method using hydroquinone as the reducing agent. In this method, $1.0 \mathrm{~cm}^{3}$ of hydroquinone was added to a $0.5 \mathrm{M} \mathrm{HCl}$ digested sample solution. The mixture was agitated and allowed to stand for 30 minutes. The blue colour that developed was determined quantitatively at 660nm using a spectrophotometer.

\section{II.7. Determination of Vitamins}

II.7.1. Determination of Vitamin A

The method adopted for the determination of vitamin A content in the samples was as described by

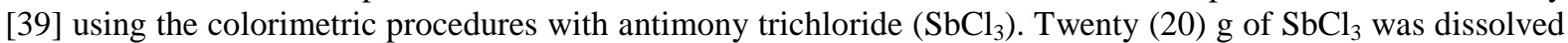
in $100 \mathrm{~cm}^{3}$ of chloroform by warming slightly on heating mantle, cooled in ice water until excess of reagent separated. The supernatant was used for colour development in all the tests. One (1)g of standard vitamin A was dissolved in $100 \mathrm{~cm}^{3}$ of chloroform. This solution contains $10 \mathrm{mg} / \mathrm{cm}^{3}$ of vitamin A. Series of $1.0,2.0,3.0$, 4.0 and $5.0 \mathrm{~cm}^{3}$ were taken from the stock solution and each made up to $10 \mathrm{~cm}^{3}$ with chloroform. Accurate volume $\left(2 \mathrm{~cm}^{3}\right)$ of the $\mathrm{SbCl}_{3}$ solution was added to these standards and allowed to stand for the colour (blue) development. Their absorbances were determined at $620 \mathrm{~nm}$ using chloroform $/ \mathrm{SbCl}_{3}$ as blank. One (1) g of ground sample was then taken in a beaker and extracted with $10 \mathrm{~cm}^{3}$ of chloroform. Using pasture pipette, the chloroform layer was taken into another test tube. This was tested with the $\mathrm{SbCl}_{3}$ reagent for the blue colour development and the absorbance read at $620 \mathrm{~nm}$. The vitamin A content of the sample was calculated as:

$$
\left[\mathrm{A}_{\mathrm{sa}} \times \mathrm{C}_{\mathrm{std}} \times \mathrm{D} . \mathrm{F}\right] \div\left[\mathrm{A}_{\mathrm{std}} \times \mathrm{Wt}_{\mathrm{sa}}\right]=\mathrm{mg} / \mathrm{l} \text { of vitamin } \mathrm{A}
$$

Where: $\quad \mathrm{A}_{\mathrm{sa}}=$ Absorbance of the sample; $\mathrm{C}_{\mathrm{std}}=$ Standard concentration; $\mathrm{D} . \mathrm{F}=$ Dilution factor;

$\mathrm{Wt}_{\mathrm{sa}}=$ Weight of the sample; $\mathrm{A}_{\mathrm{std}}=$ Absorbance of the standard

\section{II.7.2. Determination of Vitamin C (Ascorbic acid)}

Vitamin A content in the samples was determined according to the method described by [39]. Standard stock solution of $50 \mathrm{mg} / 100 \mathrm{~cm}^{3}$ ascorbic acid was first prepared by dissolving an exact amount of $50 \mathrm{mg}$ of ascorbic acid in a small amount of $6 \mathrm{~g} / 100 \mathrm{~cm}^{3}$ trichloroacetic acid (TCA) and brought to a final volume of $100 \mathrm{~cm}^{3}$ with the TCA solution. This was followed by the preparation of $5 \mathrm{mg} / 100 \mathrm{~cm}^{3}$ intermediate ascorbic acid standard by taken an aliquot of $10 \mathrm{~cm}^{3}$ of the stock standard in a $100 \mathrm{~cm}^{3}$ standard volumetric flask and diluted to a final volume of $100 \mathrm{~cm}^{3}$ with the $6 \mathrm{~g} / 100 \mathrm{~cm}^{3}$ TCA solution. In a series of $25 \mathrm{~cm}^{3}$ volumetric flasks, the 
following amount of the intermediate standard: $0.5,2.0,4.0,6.0,10.0,15.0$ and $20.0 \mathrm{~cm}^{3}$ were taken and respective volume brought to a final volume of $25 \mathrm{~cm}^{3}$ with the $6 \mathrm{~g} / 100 \mathrm{~cm}^{3}$ TCA solution to yield working standards with the concentrations of $0.10,0.40,0.80,1.20,2.00$ and 3.00 and $4.00 \mathrm{mg} / 100 \mathrm{~cm}^{3}$. An accurate amount of $1 \mathrm{~g}$ of each of the dried samples was extracted with $10 \mathrm{~cm}^{3}$ of $6 \mathrm{~g} / 100 \mathrm{~cm}^{3}$ trichloroacetic acid (TCA) solution. Accurate volume of $1 \mathrm{~cm}^{3}$ of the clear extract solutions was filtered into different test-tubes. Similarly, $1 \mathrm{~cm}^{3}$ of the ascorbic acid standards were taken in different test-tubes and $1 \mathrm{~cm}^{3}$ of the $6 \mathrm{~g} / 100 \mathrm{ml}$ TCA solution was equally taken in a test-tube as a blank. Exact amount of $1 \mathrm{~cm}^{3}$ of dinitrophenyl-hydrazine -thiourea-copper sulphate (DTCS) reagent was added to each of the test-tube, caped, mixed and incubated in a water bath at $37^{\circ} \mathrm{C}$ for 3 hours. The test-tubes were removed from the water bath, chilled for 10minutes in an ice bath and $2 \mathrm{~cm}^{3}$ of cold $12 \mathrm{M} \mathrm{H}_{2} \mathrm{SO}_{4}$ were added to each of the test-tube and mixed slowly. The spectrophotometer was adjusted with the blank to read zero absorbance at $520 \mathrm{~nm}$ and then the absorbance of standards and test samples were read. The results in $\mathrm{mg} / \mathrm{l}$ of vitamin $\mathrm{C}$ were extrapolated from the standard plot and calculated as followed:

$$
\left[\mathrm{A}_{\mathrm{sa}} \times \mathrm{C}_{\mathrm{std}} \times \mathrm{D} . \mathrm{F}\right] \div\left[\mathrm{A}_{\mathrm{std}} \times \mathrm{Wt}_{\mathrm{sa}}\right]=\mathrm{mg} / \mathrm{l} \text { of vitamin } \mathrm{C}
$$

Where: $\quad \mathrm{A}_{\mathrm{sa}}=$ Absorbance of the sample; $\mathrm{C}_{\mathrm{std}}=$ Standard concentration; D.F = Dilution factor;

$\mathrm{Wt}_{\mathrm{sa}}=\mathrm{Weight}$ of the sample; $\mathrm{A}_{\mathrm{std}}=$ Absorbance of the standard

\section{II.7.3. Determination of Vitamin E ( $\alpha$-tecopherol)}

Vitamin E content in the samples was determined according to the method described by [39]. Water extracts $(0.3 \mathrm{~g})$ of the Gongronema latifolium samples were re-dissolved separately in $20 \mathrm{~cm}^{3}$ of water and centrifuged at $15,000 \mathrm{r} \mathrm{p} \mathrm{m}$ for 20 minutes to get the supernatants. Exactly $1.0 \mathrm{~cm}^{3}$ of each supernatant was taken in different test tubes, $0.5 \mathrm{~cm}^{3}$ of absolute ethanol added and $4.0 \mathrm{~cm}^{3}$ of petroleum ether were subsequently added. These were followed by the addition of $2.0 \mathrm{~cm}^{3}$ of 4,7 -diphenyl-1,10-phenathroline. The spectrophotometer was adjusted with the blank to read zero absorbance at $520 \mathrm{~nm}$ and the absorbance of the samples read. The absorbance obtained was extrapolated from the standard curve for $\alpha$-tecopherol to get the amount of the vitamin $(\mathrm{mg})$ present in the samples.

\section{8. Data Analyses}

The analyses were performed in triplicate and data collected were analysed using Excel and Graph pad InStat-[DATA SET 1.1SD]. Differences between means were evaluated by student's t-test. Statistical significant difference was stated at $\mathrm{p}<0.05$.

\section{Results And Discussions}

The results obtained in this study are as presented in Tables 1a to 6. Table 1a showed the qualitative phytochemicals composition of the plant samples. From the table, saponin, flavonoid, steroid, triterpenoid were present in trace amounts in the two samples. Alkaloid and glycoside were present in moderate quantities. Table $1 \mathrm{~b}$ showed the quantitative phytochemicals composition of the plant samples. From the table, saponin contents were $11.93 \pm 0.09 \%$ in the cultivated sample and $9.89 \pm 0.67 \%$ in the wild samples. The saponin levels in the two samples were significantly different at $\mathrm{p}<0.05$. Saponin reacts with the cholesterol rich membrane of cancer cells, thereby limiting their growth and viability [49]. Saponins in medicinal plants are responsible for most biological effects related to cell growth and division in human and have inhibitory effect on inflammation [50]. Saponins serve as antioxidants as they prevent degeneration of DNA and also help to reduce colon damage and risk of cancer. Saponins are used as adjuvant in vaccines and their oral intake has been used to help in managing retroviral infections [51]. Alkaloid level in the cultivated sample was $27.88 \pm 0.03 \%$ while that of the wild sample was $28.25 \pm 0.02 \%$. These values were significantly different at $\mathrm{p}<0.05$. Alkaloids containing medicinal plants are reported to have been used by the early man as pain relievers and stimulants. Glycoside level in the cultivated sample was $18.11 \pm 0.02 \%$ while that of the wild sample was $20.16 \pm 0.02 \%$. These values were significantly different $(\mathrm{p}<0.05)$. Glycoside is said to help in the treatment of congestive heart failure. Flavonoid contents in the plant samples were $8.66 \pm 0.00 \%$ for the cultivated and $1.34 \pm 0.02 \%$ for the wild samples. These values were significantly different at $\mathrm{p}<0.05$. Flavonoid provides protection against cardiovascular disease by contributing to the antioxidant defense system of the human body [52]. Flavonoid is good in the management of oxidative stress [53]. Steroid level in the cultivated sample was $0.53 \pm 0.02 \%$ while that of wild sample was $0.81 \pm 0.01 \%$. These values were significantly different $(\mathrm{p}<0.05)$. Steroids are of importance in pharmacy due to their relationship with compounds such as sex hormones [53]. Tritepenoid concentration in the cultivated sample was $1.02 \pm 0.02 \%$ while that of the wild was $1.84 \pm 0.02 \%$. These values were significantly different at $\mathrm{p}<0.05$. Terpenoids act as antibiotics, protecting the plants from pathogenic micro organisms. Terpenoids also reduce diastolic blood pressure and lowers the sugar level in the blood [53]. The significant different $(\mathrm{p}<0.05)$ observed between the phytochemicals in the cultivated and wild samples could be attributed to same kinds of harsh environmental conditions in the forest as a result of both anthropogenic 
activities and factors such as rainful, humidity, pressure and temperature. However, the phytochemicals in the cultivated and wild samples were found to be highly correlated with $r=0.96$ at $p=0.05$. This indicated that the parameters may have been affected by the same anthropogenic and natural factors, meaning that as one factor increases, the other factor also increases.

Table 1a: Qualitative Phytochemical Composition of the Cultivated and Wild Gongronema latifolium Samples

\begin{tabular}{|l|l|l|}
\hline Phytochemicals & \multicolumn{2}{|l|}{ Gongronema latifolium Samples } \\
\hline Saponin & Cultivated & Wild \\
\hline Alkaloid & + & + \\
\hline Glycoside & ++ & ++ \\
\hline Flavonoid & ++ & ++ \\
\hline Steroid & + & + \\
\hline Triterpenoid & + & + \\
\hline
\end{tabular}

$++=$ Moderately present,$\quad+=$ Present in trace amount

Table 1b: Quantitative Phytochemical Composition (\%) of Gongronema latifolium Samples

\begin{tabular}{|l|l|l|}
\hline Phytochemicals & \multicolumn{2}{|l|}{ Gongronema latifolium Samples } \\
\hline & Cultivated & Wild \\
\hline Saponin & $11.93^{\mathrm{a}} \pm 0.09$ & $9.89^{\mathrm{b}} \pm 0.67$ \\
\hline Alkaloid & $27.88^{\mathrm{a}} \pm 0.03$ & $28.75^{\mathrm{b}} \pm 0.02$ \\
\hline Glycoside & $18.11^{\mathrm{a}} \pm 0.02$ & $20.61^{\mathrm{b}} \pm 0.02$ \\
\hline Flavonoid & $8.66^{\mathrm{a}} \pm 0.00$ & $1.34^{\mathrm{b}} \pm 0.02$ \\
\hline Steroid & $0.53^{\mathrm{a}} \pm 0.02$ & $0.81^{\mathrm{b}} \pm 0.01$ \\
\hline Triterpenoid & $1.02^{\mathrm{a}} \pm 0.02$ & $1.84^{\mathrm{b}} \pm 0.02$ \\
\hline
\end{tabular}

Above values are means \pm standard deviations of triplicate analyses. Within row, means with different letters are significantly different $(\mathrm{p}<0.05)$.

Table 2 showed the antinutrient contents of the plant samples. Hydrocyanic acid levels in the samples were $0.05 \pm 0.00 \mathrm{mg} / 100 \mathrm{~g}$ for the cultivated and $0.09 \pm 0.00 \mathrm{mg} / 100 \mathrm{~g}$ for the wild. The values for the hydrocyanic acid in the two samples were significantly different at $\mathrm{P}<0.05$. Cyanide ions inhibits several enzymes systems and depress growth through interference with certain essential amino acid and utilization of associated nutrients [54]. A high level of hydrocyanic acid has been implicated in celebral damage and lethargy in man [55]. Oxalate contents in the two samples were $145.20 \pm 4.40 \mathrm{mg} / 100 \mathrm{~g}$ for the cultivated and $180.40 \pm 4.40 \mathrm{mg} / 100 \mathrm{~g}$ for the wild. These values were equally significantly different at $\mathrm{p}<0.05$. Oxalate is known for its ability to bind calcium present in food thereby rendering calcium unavailable for normal physiological and biochemical roles such as maintenance of strong bones, teeth, cofactor in enzymatic reaction, nerve impulse transmission and as clothing factor in blood [56]. Phytate contents in the two plant samples were $3.65 \pm 0.03 \mathrm{mg} / 100 \mathrm{~g}$ in the cultivated and $3.56 \pm 0.03 \mathrm{mg} / 100 \mathrm{~g}$ in the wild. The values were significantly different at $\mathrm{p}<0.05$. Phytate is associated with nutritional disease such as rickets and osteomalacia in children and adults [10]. Phytic acid has a negative effect on amino acid digestibility thereby posing problems to non-ruminant animals due to insufficient amount of intrinsic factor, phytase necessary to hydrolyze the phytic acid complexes [57]. Tannin contents in the two samples were $4.85 \pm 0.06 \mathrm{mg} / 100 \mathrm{~g}$ in the cultivated and $3.29 \pm 0.07 \mathrm{mg} / 100 \mathrm{~g}$ in the wild. The values were significantly different at $\mathrm{p}<0.05$. Tannins are water soluble phenolic compounds that chelate $\mathrm{Fe}$ and $\mathrm{Zn}$ and limit their absorption [58]. In sensitive individual, a large intake of tannin may cause bowel irritation, kidney irritation, liver damage, stomach irritation and gastrointestinal pain [59]. Again, as noted for the phytochemicals, the significant difference $(\mathrm{p}<0.05)$ observed between the antinutrients in the cultivated and wild plant samples could have been attributed to some kinds of environmental conditions in the forest as a result of both the anthropogenic activities and natural factors. The antinutrients in the cultivated and wild samples were found to be perfectly correlated with $\mathrm{r}=1.00$ at $\mathrm{p}=0.05$. This indicated that the parameters could have been influenced by the same factors (both anthropogenic factors and natural factors such as rainfall, temperature and humidity).

Table 3 showed the proximate composition of the plant samples. From the table, the moisture contents were $61.80 \pm 0.03 \%$ in the cultivated sample and $65.06 \pm 0.09 \%$ in the wild sample. These values were significantly different at $\mathrm{p}<0.05$. The vegetable samples analysed had high levels of moisture contents which were closer to the ones obtained in Occimum gratissimum (84.0\%), Telfairia occidentalis (79.92\%) and Justica shinipen (78.75\%), Amaranthus virirdis (77.62\%) as reportd by [60] and [61], respectively. The results were in agreement with the report that the moisture contents of fruits and vegetables are as high as $85 \%$ [62]. Low lipid levels were recorded in the vegetable samples. The cultivated sample had a lipid level of $13.93 \pm 0.03 \%$ while the wild sample had $12.69 \pm 0.06 \%$. These values were however higher than those of Talinum triangure $(5.90 \%)$ and Amaranthus hybridus (4.80\%) reported by [63] and those of Justica schinipen (3.32 $\pm 0.02 \%)$ and Amaranthus viridis $(2.27 \pm 0.02 \%)$ reported by [61]. The low lipid levels in the vegetable samples are in agreement with the reports that leafy vegetables are poor sources of lipid. The consumption of such leafy vegetables in large amount 
is described as a good dietary habit and may be recommendable to people suffering from obesity [61]. A diet providing $1-2 \%$ of its caloric of energy as fats is said to be sufficient to human beings as excess fat consumption is implicated in certain cardiovascular disorders such as atherosclerosis, cancer and aging. High protein levels were recorded in the vegetable samples analysed. Protein contents of the cultivated and wild samples were $24.37 \pm 0.41 \%$ and $21.93 \pm 0.73 \%$ respectively. These values were significantly different at $p<0.05$. Plant proteins are sources of food nutrients especially for the less privileged population in the developing countries including. Most proteins are involved in the manufacturing of DNA, some are involved in structural support and others in bodily movement or in defence against germs. Carbohydrate contents were found to be higher in the two samples. The wild sample had a value of $48.35 \pm 0.70 \%$ while the cultivated sample had a value of $45.21 \pm 0.045 \%$. These values were significantly different at $p<0.05$. Carbohydrate is necessary for the maintenance of life in plants and animals. It serves as stored form of energy as glycogen in liver and muscles. Fibre contents of the vegetable samples were $6.92 \pm 0.03 \%$ for the cultivated and $6.93 \pm 0.02 \%$ for the wild. The two values were not significantly different at $p>0.05$. Fibre aids in speeding up the excretion of waste and toxin from the body, thus preventing them from sitting in the intestine or bowel for too long which could lead to several diseases [64]. It had been noted that adequate intake of dietary fibre can lower the serum cholesterol level and the risk of having constipation, hypertension, colon and breast cancer. Ash contents of the samples were $9.51 \pm 0.02 \%$ for the cultivated and $10.09 \pm 0.02 \%$ for the wild. The values were significantly different at $\mathrm{p}<0.05$. Ash contents account for mineral contents present in plant. As noted earlier, the significant difference $(\mathrm{p}<0.05)$ observed between the proximate composition except fibre in the cultivated and wild samples could be attributed to some kinds of harsh environmental conditions in the forest as a result of both anthropogenic activities and natural factors.

The proximate composition in the cultivated and wild samples were found to be perfectly correlated with $\mathrm{r}=1.00$ at $\mathrm{p}=0.05$. An indication that the parameters are being influenced by the same factors (both anthropogenic and natural factors).

Table 2: Antinutrient Composition $(\mathrm{mg} / 100 \mathrm{~g})$ of the Plant Samples

\begin{tabular}{|l|l|l|}
\hline Antinutrients & Gongronema latifolium Samples \\
\hline & Cultivated & Wild \\
\hline Hydrocyanic acid $(\mathrm{HCN})$ & $0.05^{\mathrm{a}} \pm 0.00$ & $0.09^{\mathrm{b}} \pm 0.00$ \\
\hline Oxalate & $145.20^{\mathrm{a}} \pm 4.40$ & $180.40^{\mathrm{b}} \pm 4.42$ \\
\hline Phytate & $3.65^{\mathrm{a}} \pm 0.03$ & $3.56^{\mathrm{b}} \pm 0.03$ \\
\hline Tannin & $4.85^{\mathrm{a}} \pm 0.06$ & $3.29^{\mathrm{b}} \pm 0.07$ \\
\hline
\end{tabular}

Above values are means \pm standard deviations of triplicate analyses. Within row, means with different letters are significantly different $(\mathrm{p}<0.05)$.

Table 3: Proximate Composition (\%) of the Plant Samples

\begin{tabular}{|l|l|l|}
\hline Proximate Composition & Gongronema latifolium Samples \\
\hline & Cultivated & Wild \\
\hline Moisture & $61.80^{\mathrm{a}} \pm 0.03$ & $65.06^{\mathrm{b}} \pm 0.09$ \\
\hline Ash & $9.51^{\mathrm{a}} \pm 0.02$ & $10.09^{\mathrm{b}} \pm 0.02$ \\
\hline Fibre & $6.92^{\mathrm{a}} \pm 0.03$ & $6.93^{\mathrm{a}} \pm 0.02$ \\
\hline Protein & $24.37^{\mathrm{a}} \pm 0.41$ & $21.93^{\mathrm{b}} \pm 0.73$ \\
\hline Carbohydrate & $45.21^{\mathrm{a}} \pm 0.45$ & $48.35^{\mathrm{b}} \pm 0.70$ \\
\hline Caloric value & $404.35^{\mathrm{a}} \pm 0.17$ & $395.36^{\mathrm{b}} \pm 0.29$ \\
\hline
\end{tabular}

Above values are means \pm standard deviations of triplicate analyses. Within row, means with different letters are significantly different $(\mathrm{p}<0.05)$.

Table 4 showed the essential elements composition of the plant samples. From the table, calcium contents were $56.38 \pm 0.04 \mathrm{mg} / 100 \mathrm{~g}$ in the cultivated sample and $57.95 \pm 0.03 \mathrm{mg} / 100 \mathrm{~g}$ in the wild. These values were significantly different at $\mathrm{p}<0.05$. Calcium is important for blood clotting and muscle contraction. It is essential for nerve impulse conduction and activation of some enzymes which generate neurotransmitters. It also plays important role in building strong bones and teeth [65]. Sodium contents in the vegetable samples were $87.09 \pm 0.03 \mathrm{mg} / 100 \mathrm{~g}$ in the cultivated and $45.27 \pm 0.03 \mathrm{mg} / 100 \mathrm{~g}$ in the wild. The values were significantly different at $\mathrm{p}<0.05$. Sodium plays important role in blood pressure regulation [66]. Potassium contents were $74.17 \pm 0.04 \mathrm{mg} / 100 \mathrm{~g}$ in the cultivated and $81.57 \pm 0.04 \mathrm{mg} / 199 \mathrm{~g}$ in the wild samples. Potassium helps in protein synthesis, it stimulates the movement of the intestinal tract. Potassium is necessary for the function of all living cell. Diet high in potassium can reduce the risk of hypertension and possibly stroke [66]. Phosphorus contents were $165.29 \pm 0.02 \mathrm{mg} / 100 \mathrm{~g}$ in the cultivated and $156.70 \pm 0.03$ in the wild samples. The two values were significantly different at $\mathrm{p}<0.05$. Phosphorus like calcium is required for growth, maintenance of bones, teeth and muscles. Magnesium contents in the vegetable samples were $10.80 \pm 0.02 \mathrm{mg} / 100 \mathrm{~g}$ in the cultivated and $6.74 \mathrm{mg} / 100 \mathrm{~g}$ in the wild. These values were significantly different at $\mathrm{p}<0.05$. Magnesium is important in 
calcium metabolism in bones and also in prevention of circulatory diseases such as ischemia heart disease [67]. Soft tissue magnesium function as a co factor of many enzymes involve in energy metabolism, protein synthesis, RNA and DNA synthesis and maintenance of electrical potential of nervous tissue and cell membranes. Iron contents in the two samples were $2.82 \pm 0.01 \mathrm{mg} / 100 \mathrm{~g}$ in the cultivated sample and $3.04 \pm 0.04 \mathrm{mg} / 100 \mathrm{~g}$ for the wild sample. Iron is vital for almost all living organisms participating in variety of metabolism processes including oxygen transport, DNA synthesis and electrons transport. Adequate iron level in the body is very important in decreasing the incidence of anemia. Again, the significance difference $(\mathrm{p}<0.05)$ observed between the essential elements composition in the cultivated and wild samples could be attributed to some kinds of harsh environmental conditions in the forest as a result of both the anthropogenic and natural factors.

The essential elements in the cultivated and wild samples were found to be highly correlated with $\mathrm{r}=$ 0.95 at $\mathrm{p}=0.05$. This indicated that the parameters could have been influenced by the same factors (both anthropogenic and natural factors such as rainfall, temperature and humidity).

Table 4: Essential Elements Composition (mg/100) of Gongronema latifolium Samples

\begin{tabular}{|l|l|l|}
\hline Elements & Gongronema latifolium Samples \\
\hline & Cultivated & Wild \\
\hline Calcium & $56.38^{\mathrm{a}} \pm 0.04$ & $57.95^{\mathrm{b}} \pm 0.03$ \\
\hline Sodium & $87.09^{\mathrm{a}} \pm 0.03$ & $45.27^{\mathrm{b}} \pm 0.03$ \\
\hline Potassium & $74.17^{\mathrm{a}} \pm 0.04$ & $81.57^{\mathrm{b}} \pm 0.04$ \\
\hline Phosphorous & $165.29^{\mathrm{a}} \pm 0.02$ & $156.70^{\mathrm{b}} \pm 0.03$ \\
\hline Magnesium & $10.80^{\mathrm{a}} \pm 0.02$ & $6.74^{\mathrm{b}} \pm 0.01$ \\
\hline Iron & $2.82^{\mathrm{a}} \pm 0.01$ & $3.04^{\mathrm{b}} \pm 0.04$ \\
\hline
\end{tabular}

Above values are means \pm standard deviations of triplicate analysis. Within row, means with different letters are significantly different $(\mathrm{p}<0.05)$.

Table 5 showed the trace metal levels in the plant samples. From the table, copper $(\mathrm{Cu})$ levels were $3.44 \pm 0.03 \mathrm{mg} / 100 \mathrm{~g}$ and $1.76 \mathrm{mg} 100 \mathrm{~g}$ in the cultivated and wild samples, respectively. The two values were significantly different at $\mathrm{p}<0.05$. $\mathrm{Cu}$ is an essential element in mammalian nutrition as a component of metalloenzymes in which it acts as an electron donor and acceptor. Cadmium (Cd) levels in the two samples were $0.01 \pm 0.00 \mathrm{mg} / 100 \mathrm{~g}$ for the cultivated and $0.01 \pm 0.01 \mathrm{mg} / 100 \mathrm{~g}$ for the wild. These values were not significantly different at $\mathrm{p}<0.05$. Lead $(\mathrm{Pb})$ level in both the cultivated and wild samples was as low as $0.01 \pm 0.00 \mathrm{mg} / 100 \mathrm{~g}$. Pb causes cancer, damage the brain and kidney and ultimately death. Cobalt (Co) level in both samples was $0.02 \pm 0.00 \mathrm{mg} / 100 \mathrm{~g}$. Co has a large significance in animal nutrition and is observed to be a component of vitamin $B_{12}$ (Cobalamine). Nickel $(\mathrm{Ni})$ levels in the vegetable samples were $0.04 \pm 0.00 \mathrm{mg} / 100 \mathrm{~g}$ for the cultivated and $0.03 \pm 0.00$ for the wild. The two values were significantly different at $\mathrm{p}<0.05$. Manganese (Mn) stood at $0.14 \pm 0.00 \mathrm{mg} / 100 \mathrm{~g}$ in the cultivated and $0.18 \pm 0.03 \mathrm{mg} / 100 \mathrm{~g}$ in the wild samples. These values were significantly different at $\mathrm{p}<0.05$. Mn deficiency can produce severe skeletal and reproductive abnormalities in mammals. Arsenic (Ar) levels in the two samples were below detection limit. Ar can impaired important biochemical process posing threat to life. The significance difference $(p<0.05)$ observed between the trace metals levels in the cultivated and wild samples could also be attributed to some kinds of harsh environmental conditions in the forest as a result of both the anthropogenic activities and natural factors. The trace metals in the cultivated and wild samples were found to be perfectly correlated with $r=1.00$ at $p=0.05$. This indicated that the metals could have been influenced by the same anthropogenic activities and natural factors such as rainfall, temperature and humidity, meaning that as one factor increases, the other factor also increases. The trace metal levels in the plant samples analysed were however, below the levels that could cause phytotoxity in plants and toxicity in humans.

Table 5: Trace metal Levels (mg/100) in the Gongronema latifolium Samples

\begin{tabular}{|l|l|l|}
\hline Trace metals & \multicolumn{3}{|l|}{ Gongronema latifolium } & \multicolumn{1}{|l|}{ samples } \\
\hline & Cultivated & Wild \\
\hline $\mathrm{Cu}$ & $3.44^{\mathrm{a}} \pm 0.03$ & $1.76^{\mathrm{b}} \pm 0.03$ \\
\hline $\mathrm{Cd}$ & $0.01^{\mathrm{a}} \pm 0.00$ & $0.01^{\mathrm{a}} \pm 0.00$ \\
\hline $\mathrm{Pb}$ & $0.01^{\mathrm{a}} \pm 0.00$ & $0.01^{\mathrm{a}} \pm 0.00$ \\
\hline $\mathrm{As}$ & $\mathrm{BDL}$ & $\mathrm{BDL}$ \\
\hline $\mathrm{Co}$ & $0.02^{\mathrm{a}} \pm 0.00$ & $0.02^{\mathrm{a}} \pm 0.00$ \\
\hline $\mathrm{Ni}$ & $0.04^{\mathrm{a}} \pm 0.00$ & $0.03^{\mathrm{b}} \pm 0.00$ \\
\hline $\mathrm{Mn}$ & $0.14^{\mathrm{a}} \pm 0.00$ & $0.18^{\mathrm{b}} \pm 0.03$ \\
\hline
\end{tabular}

Above values are means \pm standard deviations of triplicate analysis. Within row, means with different letters are significantly different $(\mathrm{p}<0.05)$. BDL $=$ Below detection limit. 
Table 6 showed the vitamin contents of the plant samples. Vitamin A contents in the samples were $1.50 \pm 0.02 \mathrm{mg} / 1000 \mathrm{~g}$ for the cultivated and $1.53 \pm 0.02 \mathrm{mg} / 100 \mathrm{~g}$ for the wild. The two values were not significantly different $(\mathrm{p}<0.05)$. Vitamin $\mathrm{A}$ is needed in small amount by humans for the normal functioning of the visual system, growth, development and maintenance of epithelial cellular integrity, immune function and reproduction. Deficiency causes night blindness. Vitamin C contents in the samples were $42.14 \pm 0.03 \mathrm{mg} / 100 \mathrm{~g}$ for the cultivated and $36.90 \pm 0.04 \mathrm{mg} / 100 \mathrm{~g}$ for the wild. The values were significantly different $(\mathrm{p}<0.05)$. Vitamin $C$ is an electron donor (reducing agent or antioxidant). Deficiency of vitamin C leads to scurvy [29, 26]. Vitamin C scavenges reactive nitrogen oxide spices to prevent nitrosation of target molecules [26 - 28]. Vitamin E contents in the plant samples were $0.03 \pm 0.00 \mathrm{mg} / 100 \mathrm{~g}$ for the cultivated and $0.01 \pm 0.00 \mathrm{mg} / 100 \mathrm{~g}$ for the wild. The two values were significantly different $(\mathrm{p}<0.05)$. Vitamin $\mathrm{E}$ is an antioxidant which is potentially able to quench free radicals. The vitamins composition in the cultivated and wild samples were found to be perfectly correlated with $r=1.00$ at $p=0.05$. This again, indicated that the parameters in the vegetable samples could have been influenced by the same anthropogenic activities and natural factors such as rainfall, temperature and humidity.

Table 6: Vitamins Composition (mg/100g) of Gongronema latifolium Samples

\begin{tabular}{|l|l|l|}
\hline Vitamins & Gongronema latifolium Samples \\
\hline & Cultivated & Wild \\
\hline A & $1.50^{\mathrm{a}} \pm 0.02$ & $1.53^{\mathrm{a}} \pm 0.02$ \\
\hline C & $42.14^{\mathrm{a}} \pm 0.03$ & $6.90^{\mathrm{b}} \pm 0.04$ \\
\hline E & $0.03^{\mathrm{a}} \pm 0.00$ & $0.01^{\mathrm{b}} \pm 0.00$ \\
\hline
\end{tabular}

Above values are means \pm standard deviations of triplicate analysis. Within row, means with different letters are significantly different $(\mathrm{P}<0.05)$.

\section{Conclusions}

Based on the analyses and results, we arrived at the following conclusions:

1. The cultivated and wild Gongronema latifolium obtained in Etinan, Akwa Ibom State contain appreciable levels of phytochemicals, nutrients, essential elements and vitamins. These qualify the plant to be listed among the groups of plants with high nutritive and medicinal properties.

2. The plant samples contain low levels of antinutrients or toxicants.

3. The plant samples equally contain low levels of trace metals.

4. The levels of antinutrients or toxicants and trace metals in this vegetable were below the levels that could cause phytotoxity in plants and toxicity in humans. Hence, the suitability of the plant for human consumption both for nutritional and medicinal purposes.

\section{References}

[1]. FAO (Food and Agricultural organization), The state of food insecurity in the World (FAO),2014, Web accessed May 1, 2015

[2]. O. A. Okunade, and K. Adesina, Preliminary study on Nutritional, Anti-nutritional and Elemental Composition of Bishop vegetable (Jatrophantanjo rensis) and cashew shoot (Anarcadium occidentale) leaves. Int. Jour. Adv. Res. Chem. Sci., 1, 2014, 43 46.

[3]. E. I. Uwah, J. Abah, N. P. Ndahi, and V.O. Ogugbuaja, Concentration Levels of Nitrate and Nitrite in soils and Some Leafy Vegetables obtained in Maiduguri, Nigeria, Journal of Applied Sciences in Environmental Sanitation 4(3), 2009,233 - 244.

[4]. A. I. Ihekoronye, and P. O. Ngoddy Integrated Food Science and Technology for the Tropics (Macmillan Education Limited, Oxford, London, 1985) $270-281$.

[5]. N. H. Ugochukwu, and N. E. Babady, Antihyperglycemic effect of aqueous and ethanolic extracts of Gongronema latifolium leaves on glucose and glycogen metabolism in livers of normal and strptozocin-induced rats, Life Sciences, 73 (15), 2003, $1925-1938$

[6]. N. H. Ugochukwu, and M. K. Coboume, Modification of renal oxidative stress and lipid preoxidation in streptozotocin-induced diabetic rats $\mathrm{C}$ treated with extracts from Gongronema latifolium leaves, Clinica Chimica Acta, 336 (1-2), $2003,73-81$.

[7]. C. Schneider, K. Rotscheidt, and E. Breithmanier, Four New Pregnane Glycosides from Gongronema latifolium 'asclepiadaceae), Journal Fur Praktcshe C'hemic., 335 (6), 1993, 532 -536.

[8]. O. Morebise,, M. A. Faflinso, J. M. Makinde, 0. A. Olayide, and E. Awe, Anti-inflammatory Property of Gongronema latifolium, Phytotherapy Research., 16, 2002, 575 -578.

[9]. C. U. Agbo, P. C. Umeh, and I. U. Obi, Genetic Variability in Protein arid Amino Acid Composition in Leaves of some Gongronema latifolium Clones, Food Global Science Books, 3(1), 2007, 98 - 106.

[10]. E. A. Moses, and E. I. Uwah, Phytochemical and Trace Metal Analyses of Selected Local Spices Plant Consumed in Uyo, Akwa Ibom, state, Nigeria, Int. J. Adv. Res. Chem. Sci., 2, 2015, 25 - 31.

[11]. Y. C. Wong, C. T. Wong, S. O. Onyiruka, and L. E. Akpanisi University Organic Chemistry, the Fundamentals (Manhatan Press (H.K.) LTD in Association with Africana - FEP Publishers LTD, 2002) 443.

[12]. A. Nostro, M. P. Germano, V. Dangelo, A. Marimo, and M. A. Cannatelli, Extraction Methods and bioautography for evaluation of medicinal plant antimicrobial activity, Lett. Appl. Microbiol., 30, 2000, 339 - 384.

[13]. K. F. Chah, C. A. Eze, C. E. Emuelosi and C. O. Esimone, Antibacterial wound healing properties of methanolic extracts of some Nigerian medicinal plants, J. Ethmopharmacol., 104, 2006, 164-167.

[14]. D. Krishnaiah, R. Sarbatly, and A. Bono, Phytochemical antioxidant for health and Medicine: A move towards nature, Biotechnol. Rev. 1, 2007, $97-104$

[15]. D. E. Okwu, Phytochemicals and vitamin content of indigenous spices of south Eastern Nigeria, J. Sustain. Agric. Environ., 6, $2004,30-34$. 
[16]. D. Herouart, R. S. Sangwan, M. A. Fliniaux, and B. S. Sangwan-Norreel, Alkaloid content of Androgenic Diploid Plants of Datura innoxia. Plants med. 54, 1988, $14-17$.

[17]. O. Ekundayo, Constitution of Gongronema !atifoiium. Benth hook (asclepiadaceae), Quarterly Journal of Crude Drug Research, 3 , $1980,127-129$.

[18]. H. U. Nwanjo, and F. O. Alumanah, Effect of Aqueous Extract of Gogroneiuu latfolium on some Indices of Liver Function in Rats, Global Journal of Medical Science 5(1), 2006, 17-20.

[19]. J. W. Lampe, Health effect of vegetables and fruit, assessing mechanism of action in Human experimental studies, American J. Clin. Nutr., 70, 1999, $475-4905$.

[20]. WHO/FAO, Requirement of vitamin A, Iron, Folate and Vitamin $B_{12}$, Report of a Joint FAO/WHO Expert consultation (Food and Nutrition series, No. 23), FAO, Rome, 1988.

[21]. J. A. Olson, Needd and sources of Carotenoids and vitamin A, Nutr. Revs. 52 (24), 1994, 567 - 573.

[22]. R. R. Rando, Retinoid isomerization reaction in the visual system. In: Blomhoff R. ed, Vitamin A in Health and Disease (New York, Marcel Dekker, Inc, 1994) 503-529.

[23]. A. Sommer, Vitamin A deficiency andits consequence: A field guide to their detection and control. $3^{\text {rd }}$ ed. (Geneva, 1994)

[24]. P. Christian, Night blindness of pregnanacy in rural Nepal-nutritional and health risk, Int.J. Epidemiol., 27, 1998, 231-237.

[25]. FAO., Human Vitamin and Mineral Requirements, Report of a joint FAO/WHO Expert Consultation Bangkok, Thailand, 2001, 1303.

[26]. E. I. Uwah, E. A. Moses, and L. P. Effiong, Vitamin C and Elemental Analyses of Two Fruit Crops Grown in Ibesikpo-Asutan, Akwa Ibom State, Nigeria, International Journal of Scientific Engineering and Applied Science, 2(1), 2016, 507 - 513.

[27]. B. Frei, L. England, and B. N. Ames, Ascorbate is an outstanding Antioxidant in Human Blood plasma, in Book of Proceedings, Natl. Acad. Sci., U S A, 86,1989, 6377- 6381.

[28]. R. A. Jacob, and G. Sotoudeh, Vitamin C Function and Status in Chronic Disease, Nutr. Clin. Care, 5, 2002, 66-74.

[29]. C. P. Stewart, and D. Guthrie, Lind's Treatise on Scurvy, Edinburgh, University Press, 1953.

[30]. G. Scott, Antioxidants in science, technology, medicine and nutrition. Chichester, Albion Publishing.

[31]. H. Sies, Oxidative Stress: an introduction. In: Oxidative stress; Oxidants and Antioxidants, Sies, H., ed. London, Academic Press, 1993, 15- 22.

[32]. R. J. Sokol, Vitamin E deficiency and neurologic disease., Ann. Rev. Nutr., 8, 1988, 351373.

[33]. N. S. Scrimshaw, Functional Consequences of Iron deficiency in Human Populations, J. Nutr. Sci. Vit., 30, 1984, 47 - 63.

[34]. J. C. Waterlow, Protein Energy Malnutrition, London, Edwin Arnold, 1992.

[35]. A. H. Shankar, and A. S. Prasad, Zinc and immune function: the biological basis of altered resistance to infection, Am. J. Clin. Nutr.,68(suppl.), 1998, 447S-463S.

[36]. G. E. Trease, and W. C. Evans, Pharmacognosy 11th Ed., Tindall Ltd, London, 1989, 60 - 75.

[37]. L. A. Sofowora, Medicinal Plants and Traditional Medicine in Africa. Spectrum Books Ltd, Ibadan, 1993, 55 -71.

[38]. G. A. Ayoola, H. A. Coker, S. A. Adesegun, A. A. Adepoju-Bello, K. Obaweya, E. C. Ezennia, and T. O. Atangbayila, Phytochemical screening and Antioxidant activities of some selected medicinal plants accessed for malaria therapy in south-western Nigeria. Trop. J. Pharm. Res., 7, 2008, 1019 - 1024.

[39]. AOAC, Methods of Analysis of Association of Official Analytical Chemists (16th ed).Washington, D.C.,1, 1997, 600-792.

[40]. J. B. Harbone, Phytochemical methods, Champman and Hall, London, 1973, 113.

[41]. B. O. Obadoni, and P.O. Ochukwu, Phytochemical studies and comparative efficacy of crude extracts of some hemeotstic plants in Edo and Delta states of Nigeria, Global Journal of pure Applied science, 8, 2001, 203-208.

[42]. R. B. Burns, Methods of estimation of tannin in the grain Sorghum. Agronomy Jour., 63, 1971, $511-514$.

[43]. M. R. Kadhakrishna, and J. Sivaprasad, Tannins content of sorghum varieties and their roles in iron bio-availability. J. Agric food chemistry, 28, 1980, 55-57.

[44]. D. Pearson, Chemical Analysis of Food, $7^{\text {th }}$ edition, Churchill, London, 1976, 7-11.

[45]. A. Munro, and O. Bassir, Oxalate in Nigerian vegetables. W. Afr. J Biol. Appl. Chem., 12, 1969, 14-18.

[46]. V. E. Wheeler, F. E, and Ferret, A Method of drought: Study of Rural Fulani, Northeastern phytic Acid Determination in Wheat Fraction. Cereal Nigeria, Int. J. Food. Sci. Nutr. 51:195-208. Chem., 48, 1971, 312-316.

[47]. E. U. Okon, and E.O. Akpanyung, Nutrients and Antinutrients in selected Brands of Malt Drinks Produced in Nigeria, Pak. J. Nutr., 4(5), 2005, 352-355.

[48]. E. N. Onyeike, T. Olungwe, and A. A. Uwakwe, Effect of heat treatment and defatting on the proximate composition of Some Nigerian local soup thickeners. Food Chem., 53, 1995, $173-175$.

[49]. R. R. Roa, R. M. Babu and R. V. Roa, Saponins as Anti - carcinogens. The J. Nutr. 125, 1995, 717 - 724.

[50]. D. E. Okwu and I. N. Emenike, Evaluation of phytonutriens and Vitamins contents of Citrus fruits Int. J. Mol. Med. Adv. Sci. 2, 2006, 1- 6 .

[51]. S. R. Chavali and J. B. Campbell, Immunomodulatory effects of orally administered saponins and non-specific resistance against rabies infection. Inter. Arch. Aller App. Immune., 84, 1987, 129 - 134.

[52]. C. K. Lyon, Sesame : Current knowledge of composition use. J. Amer. Oil Chem. Soc., 49, 1972, $245-249$.

[53]. O. U. Njoku, J. A. E. Boniface, N. C. Obitte, D. C. Odimegwu and H. I. Ogbu, Some nutriceutical potential of beniseed oil’. Int. J. Appl. Res. Nat. Prod., 2(4), 2010, $11-19$.

[54]. K.O. Soetan, and O. E Oyewale,, The Need For Adequate Processing To Reduce The Antinutritional factors in plants used as human Foods And Animal Feeds: A Review. Afr. J. Food Sci., 3, 2009, 223-232.

[55]. P. O. Agbaire and O. O. Emoyan, Nutritional and anti-nutritional levels of some local vegetables from Delta state, Nigeria .Afr. J. Food Sci. Tech., 6, 2012 8-11.

[56]. O. Ladeji, C. U. Akin and H. A. Umaru, Level of antinutritional factors in vegetables commonly eaten in Nigeria. Afr. J. Nat. Sci. 7, 2004, 71-73.

[57]. H. P. Makkar and K. Beckar, Plant toxins and detoxification methods to improve feed quality of tropical seeds. J. Animal Sci. 12, $1998,467-480$.

[58]. K. E. Akande, U. D. Doma, H. O. Agu and H. M. Adamu, Major Ant-nutrient found in plant protein sources: Their effect on nutrition. Pak. J. Nutri., 8, 2013, 827 - 832 .

[59]. S. Tanimura, R. Kadomoto, T. Tanaka, Y. J. Zhang, I. Kouno and M. Kohno, Suppression of tumor cell invasiveness by hydrolysable tannins (plant polyphenols) via the inhibition of matrix metalloproteinase $2 /-9$ activity. Bichemical and Biophysical Research Communication, 330 (4), 2009, $1306-1313$.

[60]. S. S. Sobowale, O. P. Olatidoye, O. O. Olorode and J.V. Akinlotan,. Nutritional Potentials and Chemical Values of some Tropical Leafy Vegetables Consumed in South West Nigeria. J. Sciences and Multidisciplinary Research 3, 2011, 55 -65. 
[61]. Uwah, E. I., Moses, E. A. and K. R. Okokon, Proximate, Mineral and Anti - nutrient Composition of Justica schinipen and Amaranthus viridis Consumed in Idu, Uruan, Akwa Ibom State, Nigeria, Int. J. Curr. Res. Pharm. Sci., 2 (10), 2015,24 - 30.

[62]. N. F. Jenson, Wild Plant fruit production: A Research symposium on Wild Food Plants, 32, 1978, 1-5.

[63]. A. A. Akindahunsi and S. O. Salawu, Photochemical screening and nutrient-antinutrient composition of selected tropical green vegetables. Afr. J. Biotech., 4, 2005, 497-501.

[64]. S. Hunt, I. L. Groff and J. Holbrook, Nutrition, Principles and Chemical Practice. John Wiley and Sons, New York, 1980 , 49 - 52, $459-462$.

[65]. E. I. Adeyeye and E. D. Fagbohun, Proximate, mineral and phytate profiles of some selected spices found in Nigeria, Pak. J. sci. Ind. Res, 48(1), 2005, 14-22.

[66]. T. Devesh, H. Pandey, A. N. Saha, H. S. Meenab and A. Manchandab, Pharmacognostical and biochemical investigation of Ocimum kilimandscharicum plants available in western Himalayan region, Asian Journal of plant science and Research,2(4), 2012, 446-451.

[67]. L. G. Hassan and K. J. Umar, Nutritional Value of Balsamm Apple (Momordica balsamina L.). Leaves. Pak. J. Nutr. 5 (6), 2006, $522-529$. 